\title{
Medicines for the Treatment Of COVID-19: Awaiting the Evidence
}

\section{Fármacos para Tratamento Da COVID-19: À Espera da Evidência}

\author{
Natalia MARTO $\triangle^{1,2}$, Emília C. MONTEIRO1 \\ Acta Med Port 2020 Jul-Aug;33(7-8):500-504 - https://doi.org/10.20344/amp.13908
}

\begin{abstract}
The novel severe acute respiratory syndrome coronavirus 2 is the cause of coronavirus disease 2019, a new illness with no effective treatment or vaccine that has reached pandemic proportions. In this document, we analyze how health authorities and agencies around the world position themselves regarding the off-label use of repurposed drugs or new investigational drugs to treat coronavirus disease 2019. We review the most promising candidate medicines, including available evidence, clinical recommendations and current options for access. Our concluding remarks stress the importance of administering off-label and investigational drugs in the setting of clinical trials, or at least in standardized scenarios, to generate as much scientific knowledge as achievable while engaging in the best efforts to treat patients and save lives.
\end{abstract}

Keywords: Coronavirus; Coronavirus Infections/drug therapy; COVID-19/drug therapy

\section{RESUMO}

O novo severe acute respiratory syndrome coronavírus 2 é a causa da doença por coronavírus 2019, uma doença emergente, sem tratamento eficaz nem vacina, que alcançou proporções de pandemia. Neste documento, analisamos a forma como as autoridades e agências de saúde em todo o Mundo se posicionam em relação ao uso de fármacos off-label ou novos produtos de investigação para o tratamento da doença por coronavírus 2019. Revemos os fármacos mais promissores, incluindo a evidência disponível, as recomendações clínicas e as atuais opções de acesso a estes medicamentos. Concluímos enfatizando a importância de administrar fármacos em uso off-label e produtos de investigação em contexto de ensaios clínicos, ou pelo menos em circunstâncias padronizadas, para que se gere o máximo possível de conhecimento científico a mesmo tempo que se concentram esforços em tratar doentes e salvar vidas.

Palavras-chave: Coronavírus; COVID-19/tratamento farmacológico; Infecções por Coronavírus/tratamento farmacológico

\section{INTRODUCTION}

We overcame two epidemics by Coronavirus (CoV) in our recent history: severe acute respiratory syndrome (SARS) caused by SARS CoV in 2003 and Middle East respiratory syndrome (MERS) caused by MERS Novel CoV (MERS-CoV) in 2013. Fortunately, these epidemics were contained, but not thanks to pharmacological interventions, though. In fact, the scientific community left behind these two menaces to global health empty-handed: no effective treatment and no vaccine. Although numerous therapies were tested, no new drugs emerged, in part because most studies were uncontrolled, single-arm observations and case series.

A new epidemic of CoV was first noted in December 2019 in Wuhan, Hubei province, China. ${ }^{2}$ This CoV was named novel SARS coronavirus 2 (SARS-CoV-2) and the infection Coronavirus Disease 2019 (COVID-19). COVID-19 was declared a pandemic by the World Health Organization on the $11^{\text {th }}$ March $2020 .{ }^{3}$ By Easter time in 2020, more than 1.5 million cases of COVID-19 had been reported in over 213 countries and territories, resulting in close to 100000 deaths. ${ }^{4}$

\section{NATIONAL AND INTERNATIONAL USE OF MEDICINES TO TREAT COVID-19}

China was the first country to take its toll in the
COVID-19 pandemic with more than 80000 confirmed cases and over 3000 reported deaths. ${ }^{4}$ Alone in the first response to COVID-19, China was quick to elaborate national guidelines for the treatment of COVID-19. Based on data from in vitro studies, case series and small uncontrolled trials from the SARS-CoV and MERS-CoV epidemics, the proposed treatments included lopinavir/ ritonavir (LPV/r), remdesivir, ribavirin, interferon beta, chloroquine (CQ) and hydroxychloroquine (HCQ), tocilizumab, intravenous immunoglobulin, convalescent plasma and Traditional Chinese Medicine. ${ }^{5}$ China was responsible for the dissemination of most of the currently available clinical data but unfortunately this information mostly stems from observational studies, single-arm interventions, which are uncontrolled and underpowered to provide good quality scientific knowledge.

Despite the low level of evidence, considering the urgency and the pressure healthcare systems face to save lives during the COVID-19 pandemic, some countries, including Portugal, the USA, France and Spain, have issued recommendations and protocols to allow the use of some of these drugs in patients with severe forms of COVID-19. ${ }^{6-9}$ In Portugal, the Directorate-General of Health (DGS) guideline on the management of patients with COVID-19 states that, although no drugs are approved for the treatment of COVID-19), in severe cases (pneumonia or critical disease)

1. Chronic Diseases Research Centre (CEDOC,). NOVA Medical School. Faculdade de Ciências Médicas. Universidade NOVA de Lisboa. Lisboa. Portugal.

2. Department of Internal Medicine. Hospital da Luz. Lisboa. Portugal.

$\bowtie$ Autor correspondente: Natalia Marto.nfmarto@hospitaldaluz.pt

Recebido: 12 de abril de 2020 - Aceite: 04 de maio de 2020 | Copyright @ Ordem dos Médicos 2020 
clinicians may consider the use of $\mathrm{HCQ}$, LPV/r or remdesivir. $^{6}$

The World Health Organization (WHO) displays a pragmatic perspective reinforcing there is no current evidence to recommend any specific anti-COVID-19 treatment and recommending that the use of investigational anti-COVID-19 medicines should be done under ethically approved, randomized, controlled trials. ${ }^{10}$

The European Medicines Agency (EMA) adopted a similar position and advised healthcare professionals to only use medicines, particularly $\mathrm{CQ}$ and $\mathrm{HCQ}$, for their authorized indications or as part of clinical trials or national emergency use programs for the treatment of COVID-19. ${ }^{11}$ In Portugal, the latest guidance from the Portuguese national medicines agency (Infarmed) on access to experimental therapies for COVID-19 starts by stressing the current absence of drugs approved for COVID-19, goes on to review the existing evidence for remdesivir, LPV/r and $H C Q$, lists ongoing clinical trials and ends stating the access to these drugs is very limited and dependent on an exceptional use authorization, according to the National Law on Human Medicines Use. ${ }^{12}$

In the United States, the Centers for Disease Control and Prevention (CDC) are aligned with the WHO position, ${ }^{7}$ but the national medicines agency Food and Drug Administration (FDA) issued $\mathrm{CQ}$ and $\mathrm{HCQ}$ an emergency use authorization to add the drug to the Strategic National Stockpile, thus allowing doctors to use it in cases they deem critical. ${ }^{13}$ This happened on the aftermath of president Donald Trump enthusiastically referring to HCQ as a 'phenomenal drug', and 'the biggest game changer in the history of medicine', ${ }^{14}$ after a study from France showed encouraging results for the combination of $\mathrm{HCQ}$ and azithromycin in COVID-19 treatment. $^{15}$

\section{MEDICINES CURRENTLY CONSIDERED FOR THE TREATMENT OF COVID-19}

An array of drugs approved for other indications as well as several investigational drugs are being studied in clinical trials that are underway across the globe. ${ }^{16}$

Based on currently available evidence, we will be focusing on the more promising candidate drugs being evaluated in humans infected with SARS-CoV-2 aimed at reducing mortality and disease progression: $C Q$ and $\mathrm{HCQ}$, LPV/r, remdesivir and tocilizumab. Briefly, we will mention other therapeutic options such as convalescent plasma and corticosteroids. In the Appendix (see Appendix 1: https://www.actamedicaportuguesa.com/revista/index.php/amp/article/view/13908/ Appendix_01.pdf), we provide a summary of the most relevant evidence from key clinical trials and observational studies on treatment of COVID-19.

\section{Chloroquine and hydroxychloroquine}

$\mathrm{CQ}$ and $\mathrm{HCQ}$ are antimalarial agents currently used for the treatment of malaria and autoimmune diseases such as lupus and rheumatoid arthritis. These drugs have demonstrated antiviral effects on SARS-CoV and SARS-CoV-2 in vitro: these drugs are believed to act on the entry and post-entry stages of SARS-CoV and SARS-CoV-2 infection, likely via effects on endosomal $\mathrm{pH}$ and the resulting under-glycosylation of angiotensin-converting enzyme 2 receptors that are required for viral entry. ${ }^{17}$ However, no effective activity for any viral infection has been shown in vivo, including animal models for Ebola virus or in humans for influenza and HIV. ${ }^{18}$ Both $C Q$ and HCQ have known safety profiles with the main concerns for short term use being acute cardiotoxicity, including prolonged QT syndrome and the potential for ventricular arrhythmia. Despite the scant evidence, $C Q$ and $H C Q$ were widely used for treatment of COVID-19 in China ${ }^{5}$ resulting in several uncontrolled case series and two COVID-19 small randomized clinical trials reporting conflicting results: there was no benefit in a 30-patient study, and a 62-patient trial showed reduced time to clinical recovery. ${ }^{19,20}$

$\mathrm{HCQ}$, which has a better safety profile than $C Q$ and is more widely available, received recently a boost in its use worldwide, after a small French study reported that hydroxychloroquine alone or in combination with azithromycin reduced detection of SARS-CoV-2 RNA in upper respiratory tract specimens in 20 patients compared with a nonrandomized control group of 16 patients. ${ }^{15}$ This study, which inspired president Trump's praise of $\mathrm{HCQ}^{14}$, received heavy criticism by peers for being methodologically flawed: small sample, lack of patients with severe illness, lack of blinding, no randomization, loss to follow-up, no clinical outcomes, no correlation between viral carriage and clinical outcomes, and conclusions not supported by the reported results. ${ }^{21,22}$ Microbiologist Didier Raoult and his team from Marseille then carried out a larger trial of 80 patients treated with $\mathrm{HCQ}$ and azithromycin, claiming clinical improvement and a faster reduction in viral carriage ${ }^{23}$ - but there was no control group and thus it seems problematic to attribute the observed results to the intervention. More recently, a paper from France posted on the preprint server medRxiv examined the medical records of 84 patients with COVID-19 requiring oxygen who received hydroxychloroquine and 97 similar patients who did not get the drug. Transfer to intensive care or death from any cause within seven days did not differ significantly between the groups. The researchers say the findings "do not support the use of [hydroxychloroquine] in patients hospitalized for a documented SARS-CoV-2 pneumonia". 24

Recently, the American Heart Association, American College of Cardiology, and Heart Rhythm Society have issued recommendations on the use of hydroxychloroquine and azithromycin to treat COVID-19 in patients with preexisting cardiovascular disease, reminding the effects of these two drugs in combination on QT prolongation and arrhythmia have not been studied. There is a possible additive effect, with complications including severe arrhythmia, polymorphic ventricular tachycardia, long QT syndrome, and increased risk for sudden death. ${ }^{25}$ In April, the EMA warned $C Q$ and $H C Q$ were only to be used in clinical trials or emergency use programs ${ }^{11}$ and an editorial in The BMJ also alerted to the premature and potentially harmful 
use of these drugs. ${ }^{26}$ Nevertheless, CQ and HCQ are currently presented as an option for treatment of hospitalized COVID-19 patients in several countries, including the United States, ${ }^{27}$ France $^{8}$ and Portugal. ${ }^{6,28} \mathrm{HCQ}$ is currently under investigation in clinical trials worldwide but results are not yet available. ${ }^{29}$ The WHO randomized multicenter adaptive Solidarity Trial includes a HCQ arm, and so does the European French-initiated Discovery Trial. ${ }^{30,31}$

\section{Lopinavir/Ritonavir}

Various antivirals are being trialed in patients with COVID-19 (e.g., oseltamivir, lopinavir/ritonavir, ganciclovir, favipiravir, baloxavir marboxil, umifenovir, interferon alfa) ${ }^{32}$. However, there are no data to support their use. ${ }^{10} \mathrm{LPV} / \mathrm{r}$ is a combination of antiretroviral protease inhibitors used for the treatment of human immunodeficiency virus (HIV) infection. The drug has a generally good safety profile, but may have interactions with many drugs commonly used in critically ill patients. ${ }^{33} \mathrm{LPV} / \mathrm{r}$ also has the potential for unwanted QT interval prolongation, and a risk of drug induced sudden cardiac death. ${ }^{34}$ It has weak in vitro activity against SARS-CoV-2 and MERS-CoV and was already being tested in combination with interferon beta $1 \mathrm{~b}$ for the treatment of MERS. ${ }^{35}$ It was extensively used in China for treatment of COVID-19 in adult and pediatric populations. ${ }^{5}$ The only randomized clinical trial so far included LPV/r versus placebo (plus standard of care) but it did not show promise for treatment of hospitalized COVID-19 patients with pneumonia in China, although we can argue that the lack of evidence could relate to its lack of power. ${ }^{36}$ Although guidelines from the US admit a weak recommendation against the routine use of lopinavir/ritonavir in critically ill COVID-19 patients, ${ }^{7,33}$ the drug is being used in several countries. To clarify the role of this antiviral in the treatment of COVID-19, LPV/r (with and without interferon beta) is under investigation in the WHO-sponsored Solidarity Trial and also in the Discovery Trial. ${ }^{30,31}$

\section{Remdesivir}

Remdesivir is an investigational broad-spectrum antiviral agent with in vitro activity against multiple RNA viruses, including Ebola and CoV. ${ }^{17,37}$ It is a nucleotide-analog inhibitor of RNA-dependent RNA polymerases and requires intravenous administration. Remdesivir was considered by the $\mathrm{WHO}$ as the most promising candidate based on the broad antiviral spectrum, the in vitro and in-vivo data available for coronaviruses and the extensive clinical safety database coming from a clinical trial on Ebola virus disease. ${ }^{38}$ Nevertheless, this is a drug that has not been previously approved for clinical use and could cause serious adverse effects that were not previously detected because of the very small number of exposed patients. Several randomized clinical trials, mostly manufacturer-sponsored but also the aforementioned Solidarity Trial and Discovery Trial, are currently recruiting patients with COVID-19. In addition to clinical trials, the manufacturer of remdesivir also has a compassionate-use program, although access is currently limited due to shortage of the drug resulting from overwhelming demand. ${ }^{39}$ The results of compassionateuse were published in the New England Journal of Medicine: among a cohort of 53 patients hospitalized for severe COVID-19 who received the drug, most improved, but there was no comparison group..$^{40}$ On the $29^{\text {th }}$ April 2020, the National Institutes of Health reported preliminary findings from a randomized, placebo-controlled trial of intravenous remdesivir (the Adaptive COVID-19 Treatment Trial) in 1063 patients hospitalized with COVID-19 with lung involvement. An interim analysis found that patients recovered faster with remdesivir than with placebo. Results also suggested a survival benefit. ${ }^{41}$

Remdesivir is currently the most promising drug in clinical trials for COVID-19. Further results are expected soon, as is FDA's authorization for remdesivir for treatment of COVID-19. Meanwhile, physicians around the globe are hopeful and trying to access the drug through clinical trials or compassionate use.

\section{Tocilizumab}

Tocilizumab is an anti-interleukin 6 (IL-6) monoclonal antibody approved for the treatment of rheumatoid arthritis and giant cell arteritis. IL- 6 inhibitors may cause profound immunosuppression, increasing the risk of sepsis, bacterial pneumonia, gastrointestinal perforation, and hepatotoxicity. ${ }^{42}$ The rationale for its use is that patients with COVID-19 have elevated levels of the pro-inflammatory cytokine IL-6, with the most severely ill patients exhibiting the highest levels. ${ }^{43}$ It was approved in China to treat patients with the severe form of the disease and elevated IL-6 levels. ${ }^{5}$ In the rest of the world, health agencies, including the $\mathrm{WHO}$, and guidelines have not taken a stance on the use of tocilizumab in COVID-19 due to insufficient evidence. . $10,27,33^{-13}$ Clinical trials are ongoing and spanning the United States, Canada, China, and Europe..$^{44}$ Meanwhile tocilizumab is being used in more or less controlled scenarios in hospitals around the world.

\section{Other therapeutic options}

Convalescent plasma obtained from donors recovered from COVID-19 has emerged as a potential therapy by providing passive immunity via SARS-CoV2-specific antibodies.

Over the past two decades, convalescent plasma therapy was successfully used in the treatment of SARS, MERS, and $2009 \mathrm{H} 1 \mathrm{~N} 1$ pandemic with satisfactory efficacy and safety. ${ }^{35}$ Two small case series from China showed promise for using convalescent plasma to treat critically ill and severe patients with COVID-19, improving the clinical outcomes through neutralizing viremia..$^{45,46}$ Recently, the FDA allowed physicians to apply for emergency use of investigational convalescent plasma to treat individual patients. ${ }^{47}$ Currently, most recommendations do not support its routine use in critically- or severely-ill patients. ${ }^{33,48}$

Evidence suggests that corticosteroids in patients with SARS and MERS showed no survival benefit and possible 
harm, ${ }^{5}$ although a small retrospective observational study suggested that in patients with COVID-19 pneumonia who developed acute respiratory distress syndrome (ARDS) methylprednisolone appeared to reduce the risk of death. ${ }^{49}$ At present, $\mathrm{WHO}$ and $\mathrm{CDC}$ recommend that corticosteroids should not be routinely used in patients with COVID-19 for treatment of viral pneumonia or ARDS unless indicated for another reason (e.g., asthma or chronic obstructive pulmonary disease exacerbation, septic shock). ${ }^{7,10}$

\section{CONCLUSION}

Clinicians in more than 200 countries every day face severely-ill patients with COVID-19 and witness thousands of deaths feeling desperate and powerless. They have to decide whether to administer a therapy and therefore need guidance.

At the time of this writing, no proven specific therapies are available, other than supportive care, and there is minimal evidence from clinical trials to support recommendations for the use of any specific pharmacological treatment for patients with COVID-19. National authorities around the globe have offered more or less open access to off-label anti-COVID-19 drugs, with authorization based on 'emergency use' and relying on clinical judgment. Scientific societies have released interim guidelines that are consensual only

\section{REFERENCES}

1. Kali AC. Treating COVID-19 - Off-label drug use, compassionate use, and randomized clinical trials during pandemics. JAMA. 2020;375:144856.

2. Zhu N, Zhang D, Wang W, Li X, Yang B, Song J, et al. A novel coronavirus from patients with pneumonia in China, 2019. N Engl J Med. 2020;382:727-33.

3. World Health Organization. WHO Director-General's opening remarks at the media briefing on COVID-19 11 March 2020. [accessed $2020 \mathrm{Apr}$ 8]. Available from: https://www.who.int/dg/speeches/detail/who-directorgeneral-s-opening-remarks-at-the-media-briefing-on-covid-19---11march-2020.

4. World Health Organization. Coronavirus disease (COVID-19) outbreak situation. [accessed 2020 April 12]. Available from: https://www.who.int/ emergencies/diseases/novel-coronavirus-2019.

5. China National Health Commission. Chinese Clinical Guidance for COVID-19 Pneumonia Diagnosis and Treatment $\left(7^{\text {th }} \mathrm{ed}\right)$. [accessed $2020 \mathrm{Apr}$ 12]. Available from: http://kjfy.meetingchina.org/msite/news/ show/cn/3337.html.

6. Direção-Geral de Saúde. Orientação 004/2020 COVID-19: Fase de mitigação. Abordagem do doente com suspeita ou infeção por SARSCoV-2. [accessed 2020 Mar 23]. Available from: https://www.dgs.pt/ directrizes-da-dgs/normas-e-circulares-normativas/norma-n-0042020de-23032020-pdf.

7. Centers for Disease Control. Therapeutic options for COVID-19 Patients. [accessed 2020 Apr 8]. Available from: https://www.cdc.gov/ coronavirus/2019-ncov/hcp/therapeutic-options.html\#r6. doi:10.1093/ cid/ciaa237.

8. Haut Conseil de la Santé Publique. Recommandations Thérapeutiques Dans La Prise En Charge Du COVID-19. [accessed 2020 Apr 12]. Available from: https://sfar.org/avis-relatif-aux-recommandationstherapeutiques-dans-la-prise-en-charge-du-covid-19/.

9. Agencia Espanola de Medicamientos e Productos Sanitarios. Tratamientos disponibles para el manejo de la infección respiratoria por SARS-CoV-2. [accessed 2020 Apr 12]. Available from: https://www. aemps.gob.es/la-aemps/ultima-informacion-de-la-aemps-acerca-delcovid\%E2\%80\%9119/tratamientos-disponibles-para-el-manejo-de-lainfeccion-respiratoria-por-sars-cov-2/?lang=en.

10. World Health Organization. WHO Clinical management of severe acute respiratory infection (SARI) when COVID-19 disease is in stressing the lack of evidence of benefit and providing weak recommendations for the use of a few drugs reserved for the most severe patients.

There is an emergent need for information, but information must be accurate and evidence-based. Ideally, every patient being treated for COVID-19 should be enrolled in an ethically-approved, randomized, controlled clinical trial. When a trial is unavailable, individual patients may be offered investigational therapeutics on an emergency basis but standardized data need to be collected.

In the urge to save lives and do one's best, clinicians must always be reminded: the only way we will overcome this pandemic with an effective and safe medicine for COVID-19 is if we generate scientific knowledge at the same time as we are treating the patients.

\section{COMPETING INTERESTS}

The authors have declared that no competing interests exist.

\section{FUNDING SOURCES}

This research received no specific grant from any funding agency in the public, commercial, or not-for-profit sectors.

suspected. [accessed 2020 Mar 13]. Available from: https://www.who. int/internal-publications-detail/clinical-management-of-severe-acuterespiratory-infection-when-novel-coronavirus-(ncov)-infection-issuspected\%0Ahttp://apps.who.int/iris/bitstream/10665/178529/1/WHO_ MERS_Clinical_15.1_eng.pdf.

11. European Médicines Agency. COVID-19: chloroquine and hydroxychloroquine only to be used in clinical trials or emergency use programmes | European Medicines Agency. [accessed 2020 Apr 10]. Available from: https://www.ema.europa.eu/en/news/covid19-chloroquine-hydroxychloroquine-only-be-used-clinical-trialsemergency-use-programmes.

12. Infarmed. Orientações de Acesso a Terapêuticas Experimentais No Tratamento de COVID-19 - Infeção Pelo SARS-CoV-2 [accessed $2020 \mathrm{Apr}$ 2]. Available from: https://www.infarmed.pt/ documents/15786/3584301/Orientações+de+Acesso+a+Terapêuticas+ Experimentais+no+tratamento+de+COVID-19+-+infeção+pelo+SARSCoV-2/c9595d6a-6a2f-255d-1f45-668b20db0ed6.

13. Food and Drug Administration. Request for emergency use. Authorization for use of chloroquine phosphate or hydroxychloroquine sulfate supplied from the Strategic National Stockpile for treatment of 2019 coronavirus disease. [accessed 2020 Apr 10]. Available from: https://www.fda.gov/ media/136534/download.

14. New York Times. Ignoring expert opinion, Trump again promotes use of hydroxychloroquine. [accessed $2020 \mathrm{Apr} 10$ ]. Available from: https:// www.nytimes.com/2020/04/05/us/politics/trump-hydroxychloroquinecoronavirus.html.

15. Gautret P, Lagier JC, Parola P, Hoang VT, Meddeb L, Mailhe M, et al Hydroxychloroquine and azithromycin as a treatment of COVID-19: results of an open-label non-randomized clinical trial. Int J Antimicrob Agents. 2020:105949. doi:10.1016/j.ijantimicag.2020.105949.

16. ClinicalTrials.gov NIH. Interventional Studies | Corona Virus Infection. [accessed $2020 \mathrm{Apr}$ 10]. Available from: https://www.clinicaltrials.gov/ ct2/results?cond=Corona+Virus+Infection\&recrs=b\&recrs=a\&age_v=\& gndr=\&type=Intr\&rslt=\&Search=Apply.

17. Wang M, Cao R, Zhang L, Yang X, Liu J, Xu M, et al. Remdesivir and chloroquine effectively inhibit the recently emerged novel coronavirus (2019-nCoV) in vitro. Cell Res. 2020;30:269-71.

18. American Society of Healthcare Pharmacists. Assessment of evidence for COVID-19-related treatments. [accessed 2020 Apr 25]. Available 

resource-centers/Coronavirus/docs/ASHP-COVID-19-Evidence-Table. ashx.

19. Chen J, Liu D, Liu L, Liu P, Xu Q, Xia L, et al. A pilot study of hydroxychloroquine in treatment of patients with common coronavirus disease-19 (COVID-19). J Zhejiang Univ. 2020:1-10.

20. Chen Z, Hu J, Zhang Z, Jiang S, Han S, Yan D, et al. Efficacy of hydroxychloroquine in patients with COVID-19: results of a randomized clinical trial. MedRxiv (preprint). doi.org/10.1101/2020.03.22.20040758.

21. Dahly D, Gates S, Morris T. Statistical review of Hydroxychloroquine and azithromycin as a treatment of COVID-19: results of an open-label non-randomized clinical trial. (Version 1.1). Zenodo. doi.org/10.5281/ zenodo.3725560

22. PubPeer The Online Journal Club. [accessed 2020 Apr 27]. Available from: https://pubpeer.com/publications/ E09AC9D25125B0AB077971FBA6DD7B.

23. Gautret P, Lagier L, Parola P, Hoang VT, Meddeb L, Sevestre J, et al. Clinical and microbiological effect of a combination of hydroxychloroquine and azithromycin in 80 COVID-19 patients with at least a six-day follow up: a pilot observational study. Travel Med Infect Dis. 2020:101663. doi:10.1016/j.tmaid.2020.101663.

24. Mahevas M, Tran VT, Roumier M, Chabrol A, Paule R, Guillaud C, et al. No evidence of clinical efficacy of hydroxychloroquine in patients hospitalized for COVID-19 infection with oxygen requirement: results of a study using routinely collected data to emulate a target trial. MedRxiv (preprint). doi:10.1101/2020.04.10.20060699.

25. Roden DM, Harrington RA, Poppas A, Russo AM. Considerations for drug interactions on QTc in exploratory COVID-19 (coronavirus disease 2019) treatment. Circulation. 2020;19:1-6.

26. Ferner RE, Aronson JK. Chloroquine and hydroxychloroquine in covid-19. Use of these drugs is premature and potentially harmful. BMJ. 2020;369:m1432. doi:10.1136/bmj.m1432.

27. Wilson KC, Chotirmall SH, Bai C, Rello J. COVID-19: Interim guidance on management pending empirical evidence; from an American Thoracic Society-led international task force. [accessed 2020 Apr 3]. Available from: https://www.thoracic.org/professionals/clinical-resources/diseaserelated-resources/covid-19-guidance.pdf.

28. Sociedade Portuguesa de Medicina Intensiva. Recomendações da Sociedade Portuguesa de Cuidados Intensivos e Grupo Infeção e Sépsis para a abordagem do COVID-19 em Medicina Intensiva. [accessed 2020 Mar 11]. Available from: https://www.spci.pt/media/ covid-19/COVID 19_R 20200331.pdf.

29. Hydroxychloroquine on clinicaltrials.gov. [accessed $2020 \mathrm{Apr}$ 11]. Available from: https://www.clinicaltrials.gov/ct2/results?recrs=ab\&con $\mathrm{d}=$ Corona+Virus+Infection \&term $=$ Hydroxychloroquine \&cntry $=$ \&state $=$ \& city=\&dist $=$

30. World Health Organization. Solidarity Trial. [accessed 2020 Apr 10]. Available from: https://www.who.int/emergencies/diseases/novelcoronavirus-2019/global-research-on-novel-coronavirus-2019-ncov/ solidarity-clinical-trial-for-covid-19-treatments.

31. Inserm. Discovery Trial. [accessed 2020 Apr 10]. Available from: https://presse.inserm.fr/en/launch-of-a-european-clinical-trial-againstcovid-19/38737/.

32. Antivirals on clinicaltrials.gov. [accessed 2020 Apr 10]. Available from: https://www.clinicaltrials.gov/ct2/results?cond=Corona+Virus+Infection \&term $=$ antiviral\&cntry $=\&$ state $=\&$ city $=\&$ dist $=\&$ Search $=$ Search $\&$ recrs $=a \&$ recrs $=b$.

33. Alhazzani W, Møller MH, Arabi YM, Loeb M, Ng Gong M, Fan E, et al. Surviving Sepsis Campaign: guidelines on the management of critically ill adults with coronavirus disease 2019 (COVID-19). Intensive Care Med. 2020 (in press). doi:10.1007/s00134-020-06022-5

34. Giudicessi JR, Noseworthy PA, Friedman PA, Ackerman MJ. Urgent
Guidance for Navigating and Circumventing the QTc Prolonging and Torsadogenic Potential of Possible Pharmacotherapies for COVID-19. Mayo Clin Proc. 2020 (in press). doi:10.1016/j.mayocp.2020.03.024

35. Momattin H, Mohammed K, Zumla A, Memish ZA, Al-Tawfiq JA. Therapeutic options for Middle East respiratory syndrome coronavirus (MERS-CoV) - possible lessons from a systematic review of SARS-CoV therapy. Int J Infect Dis. 2013;17:e792-8.

36. Cao B, Wang Y, Wen D, Liu W, Wang J, Fan G, et al. A trial of lopinavirritonavir in adults hospitalized with severe covid-19. N Engl J Med. 2020 (in press). doi:10.1056/NEJMoa2001282

37. Sheahan TP, Sims AC, Leist SR, Schäfer A, Won J, Brown AJ, et al. Comparative therapeutic efficacy of remdesivir and combination lopinavir, ritonavir, and interferon beta against MERS-CoV. Nat Commun. 2020;11:222. doi:10.1038/s41467-019-13940-6.

38. World Health Organization. WHO R\&D Blueprint Informal Consultation on Prioritization of Candidate Therapeutic Agents for Use in Novel Coronavirus 2019 Infection. [accessed 2020 Jan 24]. Available from: https://apps.who.int/iris/bitstream/handle/10665/330680/WHO-HEORDBlueprint\%28nCoV\%29-2020.1-eng.pdf.

39. Gilead Sciences. Emergency access to remdesivir outside of clinical trials. [accessed $2020 \mathrm{Apr}$ 12]. Available from: https://www.gilead. $\mathrm{com} /$ purpose/advancing-global-health/covid-19/emergency-access-toremdesivir-outside-of-clinical-trials.

40. Grein J, Ohmagari N, Shin D, Diaz G, Asperges E, Castagna A, et al. Compassionate use of remdesivir for patients with severe Covid-19. N Engl J Med. 2020 (in press). doi:10.1056/nejmoa2007016.

41. National Institute of Allergy and Infecious Disease. NIH clinical tria shows remdesivir accelerates recovery from advanced COVID-19. [accessed $2020 \mathrm{Apr}$ 30]. Available from: https://www.niaid.nih.gov/ news-events/nih-clinical-trial-shows-remdesivir-accelerates-recoveryadvanced-covid-19.

42. Genentech. Actemra (tocilizumab). Prescribing information. [accessed 2020 Apr 8]. Available from: https://www.actemrahcp.com/?_ga=2. 137041460.509331555.1584929819-505112783. 1584929819 E2.

43. Chen G, Wu D, Guo W, Cao Y, Huang D, Wang $H$, et al. Clinical and immunologic features in severe and moderate Coronavirus Disease 2019. J Clin Invest. 2020 (in press). doi:10.1172/jci137244.

44. ClinicalTrials.gov. Tocilizumab ClinicalTrials. [accessed 2020 Apr 8]. Available from: https://clinicaltrials.gov/ct2/results?cond=Corona+Virus +Infection\&term=tocilizumab\&cntry=\&state=\&city=\&dist=.

45. Shen C, Wang Z, Zhao F, Yang Y, Li J, Yuan J, et al. Treatment of 5 critically ill patients with COVID-19 with convalescent plasma. JAMA. 2020 (in press). doi:10.1001/jama.2020.4783.

46. Duan K, Liu B, Li C, Zhang H, Yu T, Qu J, et al. Effectiveness of convalescent plasma therapy in severe COVID-19 patients. Proc Natl Acad Sci U S A. 2020 (in press). doi:10.1073/pnas.2004168117,

47. Food and Drug Administration. Recommendations for Investigational COVID-19 Convalescent Plasma. [accessed 2020 Apr 8]. Available from: https://www.fda.gov/vaccines-blood-biologics/investigational-newdrug-ind-or-device-exemption-ide-process-cber/recommendationsinvestigational-covid-19-convalescent-plasma\#Pathways $\% 20$ for.

48. Bhimraj A, Morgan RL, Shumaker AH, Lavergne V, Baden L, Cheng VC, et al. Infectious Diseases Society of America Guidelines on the Treatment and Management of Patients with COVID-19 Infection. [accessed $2020 \mathrm{Apr}$ 11]. Available from: https://www.idsociety.org/ globalassets/idsa/practice-guidelines/covid-19/treatment/idsa-covid-19gl-tx-and-mgmt-v1.0.4.pdf.

49. Wu C, Chen X, Cai Y, Xia J, Zhou X, Xu S, et al. Risk factors associated with acute respiratory distress syndrome and death in patients with Coronavirus Disease 2019 pneumonia in Wuhan, China. JAMA Intern Med. 2020 (in press). doi:10.1001/jamainternmed.2020.0994. 